\title{
Role of an In Planta-Expressed Xylanase of Xanthomonas oryzae pv. oryzae in Promoting Virulence on Rice
}

\author{
R. Rajeshwari, Gopaljee Jha, and Ramesh V. Sonti \\ Centre for Cellular and Molecular Biology, Uppal Road, Hyderabad - 500 007, India
}

Submitted 22 October 2004. Accepted 29 March 2005.

\begin{abstract}
Xanthomonas oryzae pv. oryzae is the causal agent of bacterial leaf blight, a serious disease of rice. We demonstrated earlier that the type II secretion system (T2S) is important for virulence of $X$. oryzae pv. oryzae and that several proteins, including a xylanase, are secreted through this system. In this study, the $x y n B$ gene encoding for the secreted xylanase was cloned as a 6.9-kb EcoRI fragment (pRR7) that also included a paralog called $x y n A$. As in $X$. oryzae pv. oryzae, $x y n A$ and $x y n B$ are adjacent to each other in $X$. axonopodis pv. citri, whereas only the $x y n A$ homolog is present in $X$. campestris pv. campestris. Mutations in $x y n B$ but not $x y n A$ affect secreted xylanase activity. Western blot analysis using anti-XynB antibodies on exudates from infected rice leaves indicated that this xylanase is expressed during in planta growth. Another T2S-secreted protein was identified to be a lipase/esterase (LipA) based on the sequence tags obtained by tandem mass spectrometry analysis and biochemical assays. Mutations in either $x y n B$ or lipA partially affected virulence. However, a lipA-xynB double mutant was significantly reduced for virulence, and the pRR7 clone containing an intact $x y n B$ gene could complement the virulence-deficient phenotype of the lipA-xynB mutant. Our results suggest that there is functional redundancy among the T2S secreted proteins of $X$. oryzae $\mathrm{pv}$. oryzae in promoting virulence on rice.
\end{abstract}

Additional keywords: cell-wall-degrading enzymes, rice pathogen.

The cellulose and hemicellulose components of plant cell walls, which provide strength and rigidity, also act as a barrier for pathogens. Cell-wall-degrading enzymes, including cellulases, pectinases, xylanases, and proteases, are secreted by phytopathogenic bacteria for breaking down the components of host cell walls. The presence of 30 to 40 genes potentially encoding for cell-wall-degrading enzymes in the genome sequences of Xanthomonas campestris pv. campestris and $X$. axonopodis pv. citri is an indicator of the likely importance of these genes in the plant pathogenesis of xanthomonads (da Silva et al. 2002).

Xylan is an important component of the hemicellulose complex in plant cell walls. The cell walls of rice and other grasses have an unusually high composition of xylan, accounting for

Corresponding author: R. V. Sonti; Telephone: +91-40-27192577; Fax: +91-40-27160591; E-mail: sonti@ccmb.res.in; rvsonti@yahoo.com

Nucleotide and amino acid sequence data are available at GenBank under accession number AF331922 and AY627913. up to $60 \%$ of the total cell wall carbohydrate (Caprita and Gibeaut 1993; Takeuchi et al. 1994). Xylan is a polymer consisting of a linear backbone of 1,4-linked D-xylanopyranosyl residues and side chains of arabinose, glucuronic acid, or methylglucuronic acid. Additional modifications in the form of acetyl and phenolic esters contribute to the complexity of xylan. Several sets of enzymes are required to degrade xylan to xylose monomers. The endo- or exo- $\beta$-xylanases hydrolyze the backbone to yield xylo-oligosaccharides. Another enzyme, $\beta$ xylosidase, cleaves the 1-4- $\beta$ linkages to yield xylose monomers. Additional sets of enzymes are required for cleaving the side-chain residues, which vary depending on the nature of the side chains among different plant types. Of particular relevance to this study are the esterases that are involved in hydrolyzing acetyl ester and phenolic ester bonds in xylan. Xylanases and esterases as well as the other enzymes that cleave the side chains have been shown to act cooperatively in degrading xylan (Bachmann and McCarthy 1991; Biely et al. 1986; Saha and Bothast 1999).

Xylanases have been isolated from a wide range of microorganisms (Kulkarni et al. 1999) and can be assigned to two major families (10 or F and 11 or G) of glycosyl hydrolases, based on the primary sequence classification scheme of Henrissat and Bairoch (1993). The two families differ significantly in molecular mass, isoelectric points, substrate preferences, and the nature of oligoxylosides generated as products (Biely et al. 1997). Family 10 xylanases are larger (30 kDa and above), more complex, produce smaller oligosaccharides, and fold into $\alpha / \beta$ barrel, with approximately $40 \%$ of the secondary structure of the enzyme being $\alpha$-helix. Family 11 members are much smaller $(<30 \mathrm{kDa})$, fold into structures composed primarily of $\beta$-strands, and are more specific for xylan. The differences in their structural domains may have evolved as a result of the abundance and heterogeneity of xylan in plant cell walls.

We had earlier demonstrated that a type II protein secretion system (T2S) is required for virulence of $X$. oryzae pv. oryzae and several proteins, including a xylanase, are secreted through this system (Ray et al. 2000). In this article, we describe the characterization of $x y n B$, the gene for secreted xylanase, and assess its role in virulence of $X$. oryzae pv. oryzae.

\section{RESULTS}

\section{Cloning and sequence}

of $x y n B$ gene encoding a secreted xylanase.

Two degenerate oligonucleotide primers were used to amplify an 800-bp xylanase gene fragment by polymerase chain reaction (PCR) from genomic DNA of $X$. oryzae pv. oryzae. The cloned product (pXyn8) exhibited approximately $60 \%$ iden- 
tity at the amino acid level to family 10 xylanases from a wide range of microorganisms, including Rhodothermus marinus, Aspergillus niger, and Magnaporthe grisea. The 800-bp fragment was used to clone a 6.9-kb genomic EcoRI fragment (pRR7) which was further sequenced.

The 6,904-bp sequence revealed the presence of one incomplete and four complete open reading frames (ORFs) (Fig. 1). Sequence comparisons with the genome sequences of $X$. axonopodis pv. citri and $X$. campestris pv. campestris showed high homology to genes in these organisms. The incomplete ORF1 ( $\operatorname{sidA}$ ) of 378 bp exhibited $97 \%$ nucleotide sequence identity to putative TonB-dependent receptor genes from $X$. axonopodis pv. citri (AAM39091) and X. campestris pv. campestris (AAM43341) as well as $57 \%$ identity and $71 \%$ similarity at the amino acid level to a TonB-dependent receptor from Caulobacter crescentus (accession number AAK24796). ORF2 encoded a 493-amino-acid (aa) protein, which showed substantial similarity to putative ExuT protein from $X$. axonopodis pv. citri (accession number AAM39090; identity 84\%, similarity $89 \%$, in a stretch of 493 aa) and X. campestris pv. campestris (accession number AAM43340; identity 79\%, similarity $83 \%$ ). ORF2 also showed $33 \%$ identity and $48 \%$ similarity in a stretch of 352 aa to ExuT (galacturonate transporter) from $\mathrm{Er}$ winia chrysanthemi (accession number U35884) and 26\% identity and $45 \%$ similarity to ExuT (glucuronate transporter) from Bacillus subtilis (accession number NP388130).

ORFs 3 and 4, encoding for 329- and 325-aa proteins, were designated as $x y n A$ and $x y n B$, respectively. The predicted amino acid sequences showed 55\% identity and $67 \%$ similarity to each other and approximately $50 \%$ identity and $60 \%$ similarity to the catalytic domain (592 to 889 aa) of a 993 -aa xylanase from $R$. marinus (accession numberY11564). A predicted signal peptide of 22 aa, with the most likely cleavage site

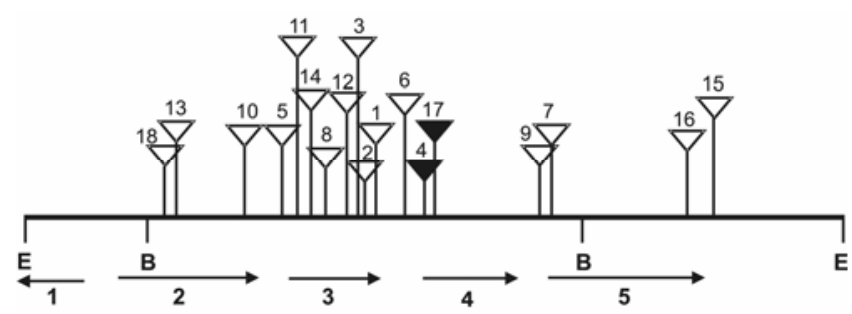

Fig. 1. Schematic of the arrangement of open reading frames (ORFs) in a 6,904-bp genomic region of Xanthomonas oryzae pv. oryzae. ORF1: putative Ton B dependent receptor; ORF2: putative hexuronate transporter; ORF3: putative xylanase A; ORF4: secreted xylanase B; ORF5: putative uronate isomerase. Arrows indicate the direction of transcription. Filled triangles indicate transposon insertions affecting xylanase secretion, whereas open triangles indicate insertions that do not affect xylanase secretion. E and B represent sites for restriction by EcoRI and BamHI, respectively. between A22 and G23, was detected only in XynB. A National Center for Biotechnology Information (NCBI) conserved domain database search showed the presence of the catalytic domain of xylanase in both XynA and XynB but the absence of a cellulose-binding domain present in several other xylanases. The predicted xynA product indicated $71 \%$ identity and $75 \%$ similarity to putative xylanase from $X$. axonopodis pv. citri (accession numberAAM39089) and 61\% identity and $73 \%$ similarity to putative xylanase from $X$. campestris pv. campestris (accession number AAM43339). The predicted $x y n B$ product showed substantial similarity to a putative xylanase of $X$. axonopodis pv. citri (accession number AAM39087; identity $95 \%$, similarity $98 \%$ in a stretch of 292 aa). The six conserved regions found in the predicted sequences of the genes for family 10 xylanases from other bacteria (Gilkes et al. 1991) also were present in the $\mathrm{XynB}$ sequence of $X$. oryzae pv. oryzae, indicating that XynB belongs to family 10 of xylanases (Fig. 2). The two glutamic acid residues reported as essential for the activity of xylanaseA in Streptomyces lividans (Moreau et al. 1994) were found in the conserved region (Fig. 2, marked with an asterisk).

ORF 5 encoded for a 472-aa protein, which is homologous (92\% identity, $95 \%$ similarity across $100 \%$ coverage of the protein) to putative uronate isomerase of $X$. axonopodis pv. $\mathrm{ci}$ tri (accession number AAM39086) and X. campestris pv. campestris (accession number AAM43338; 85\% identity, 89\% similarity in a stretch of 467 aa). The 286 nucleotides at the $3^{\prime}$ end of pRR7 exhibited $90 \%$ identity at the nucleotide level to the noncoding $3^{\prime}$ region of $p t h B$ pathogenicity gene from the cassava pathogen, X. campestris pv. manihotis (AFO12325).

The gene organization in the $x y n A-x y n B$ region of $X$. oryzae pv. oryzae was compared with that of the corresponding region in the genomes of $X$. campestris pv. campestris and X. axonopodis pv. citri (da Silva et al. 2002). The number, type, and orientation of the ORFs was similar in both $X$. axonopodis pv. citri and $X$. oryzae pv. oryzae. However, the intergenic region between $x y n A$ and $x y n B$ in $X$. oryzae pv. oryzae was noncoding; whereas, in $X$. axonopodis pv. citri, an incomplete 426-bp ORF showing $66 \%$ identity to the ORF2 from X. oryzae pv. oryzae was present between the two xylanase ORFs. The genome organization in $X$ campestris pv. campestris differed from $X$. oryzae pv. oryzae and $X$. axonopodis pv. citri by the absence of the $x y n B$ ORF in that region.

\section{Functional mapping of pRR7 by transposon mutagenesis and marker exchange.}

The 18 transposon insertions obtained in the pRR7 insert were marker exchanged in the wild-type background, and the marker-exchange mutants were assessed for xylanase secretion. Two transposon insertions in the $x y n B$ gene affected xylanase secretion and all other insertions were xylanase proficient, in-
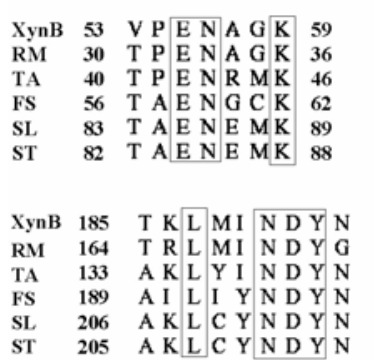

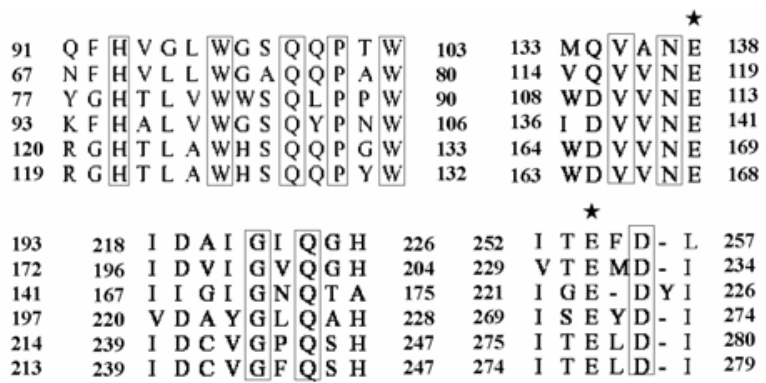

Fig. 2. Comparison and alignment of the conserved regions of XynB with those of family 10 xylanases. The amino acid residues that are identical in all the sequences are boxed. Active site residues of family 10 xylanases are marked by asterisks. XynB and RM-Xyn1 = xylanase B from Xanthomonas oryzae pv. oryzae and Rhodothermus marinus, respectively; TA = Thermomonospora aurantiacus; FS = XynB from Fibrobacter succinogenes; SL = XynA from Streptomyces lividans; ST-Xyn1 = xylanase B from Streptomyces thermoviolaceus. 
cluding the eight insertions in $x y n A$. The extracellular protein profiles of $x y n B$ strains were marked by the absence of a 32 $\mathrm{kDa}$ band, whereas the $x y n A$ mutant strains were similar to the wild-type strain when analyzed by sodium dodecyl sulfate polyacrylamide gel electrophoresis (SDS-PAGE) (Fig. 3A). The complementing pRR7 clone restored the 32-kDa product (data not shown) and xylanase activity (Fig. 3B) to the $x y n B$ mutants, indicating that the $32-\mathrm{kDa}$ protein is the product of the $x y n B$ gene. Neither secreted xylanase activity nor a protein band could be associated with the $x y n A$ gene.

\section{XynB protein is expressed}

\section{during in planta growth of $X$. oryzae pv. oryzae.}

Xylanase was purified from the culture supernatants of peptone sucrose (PS)-grown $X$. oryzae pv. oryzae strains. Passage through MonoS columns resulted in separation of at least four protein fractions upon elution with 0 to $0.2 \mathrm{M} \mathrm{NaCl}$ gradient. Xylanase activity was associated with fraction number 1 , which eluted with approximately $0.12 \mathrm{M} \mathrm{NaCl}$ (Fig. 4). The purified xylanase appeared as a single band of $32 \mathrm{kDa}$ on SDS-PAGE gels upon staining with Coomassie Blue R250 (Fig. 4) or with silver nitrate (data not shown). Polyclonal anti-
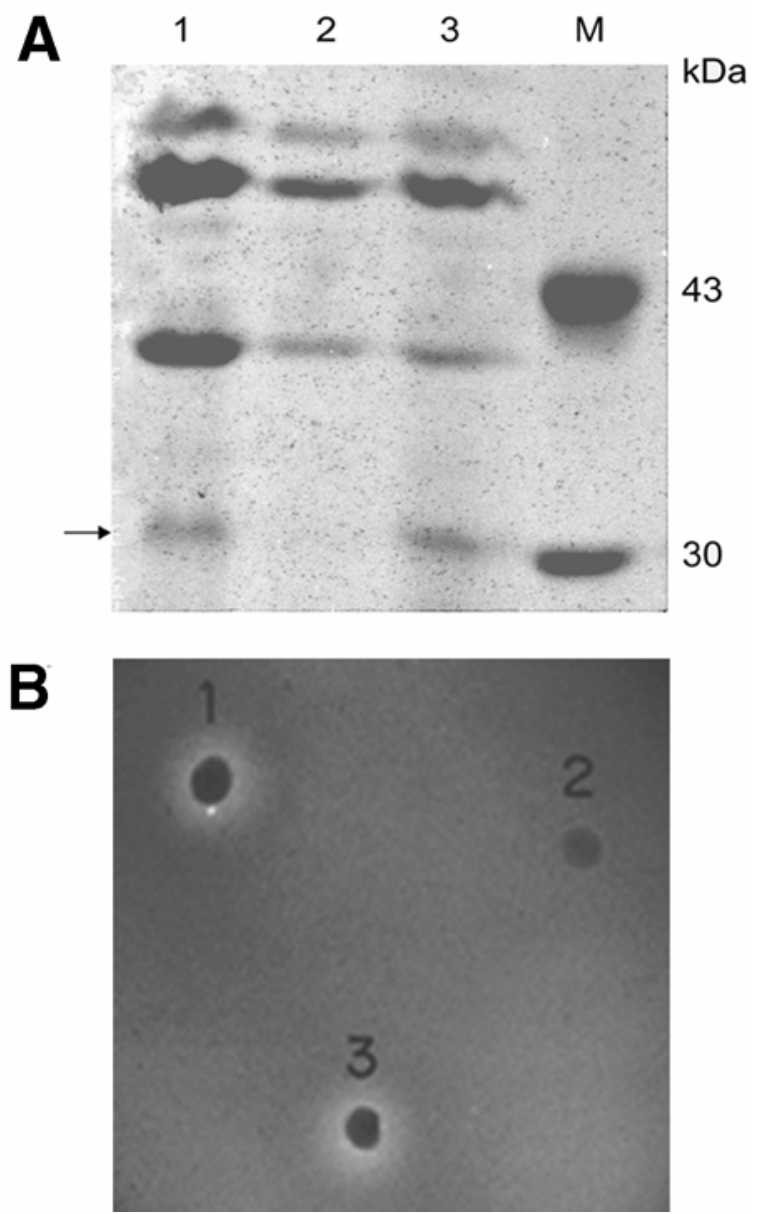

Fig. 3. A, Analysis of extracellular protein fractions from Xanthomonas oryzae pv. oryzae strains by sodium dodecyl sulfate polyacrylamide gel electrophoresis. Lane 1: BXO43 (wild-type); lane2: BXO201 (xynB1::Ty2); lane 3: BXO203 (xynA1::Ty2); lane 4: low molecular mass markers (Pharmacia). Note the 32-kDa band is absent in lane 2. Proteins were stained with Coomassie Blue R250. Arrow indicates the 32-kDa product of the $x y n B$ gene. B, Xylanase activity in $X$. oryzae pv. oryzae strains on peptone sucrose agar plates containing Remazol Brilliant Blue-xylan. 1, BXO43 (wild-type strain); 2, BXO201 (xynB1::Ty2); 3, BXO204 (BXO201/pRR7). Presence of halo around the colony indicates xylanase proficiency. bodies were raised against the purified protein. Western blot analysis of the xylem sap collected from infected leaves was performed to examine whether xylanase is secreted within the plant. A band corresponding to $32 \mathrm{kDa}$, which is the expected size of the processed XynB protein, was detected only in xylem sap of leaves infected with the wild-type and $x y n A$ mutant strains but not in the leaves infected with the $x y n B$ mutant (Fig. 5).

Fraction number 3 resolved as a single band of $39-\mathrm{kDa}$ protein when analyzed in SDS-PAGE. Two sequence tags, GYVVVSTDYLGLG and TSNFLTSYT, generated by tandem mass spectrometry (MS-MS) analysis of this band, matched conserved hypothetical proteins from $X$. axonopodis pv. citri (accession number AAM35390) and X. campestris pv. campestris (accession number AAM42229). The amino acids in the sequence tags (except for those underlined) were identical to the corresponding sequence of the $X$. axonopodis pv. citri homologue. An NCBI conserved domain database search (Marchler Bauer et al. 2003) with the predicted protein sequences of homologues from $X$. axonopodis pv. citri and $X$. campestris pv. campestris revealed the presence of an LIP domain found in secreted lipases. The purified 39-kDa protein tested positive for lipase/esterase when spotted on peptone sucrose agar (PSA) containing either $\mathrm{CaCl}_{2}$ and Tween 80 or Tributyrin as a substrate. The purified protein exhibited lipase/ esterase activity (6.65 nmoles p-nitrophenol released $/ \mathrm{min} / \mu \mathrm{g}$ )

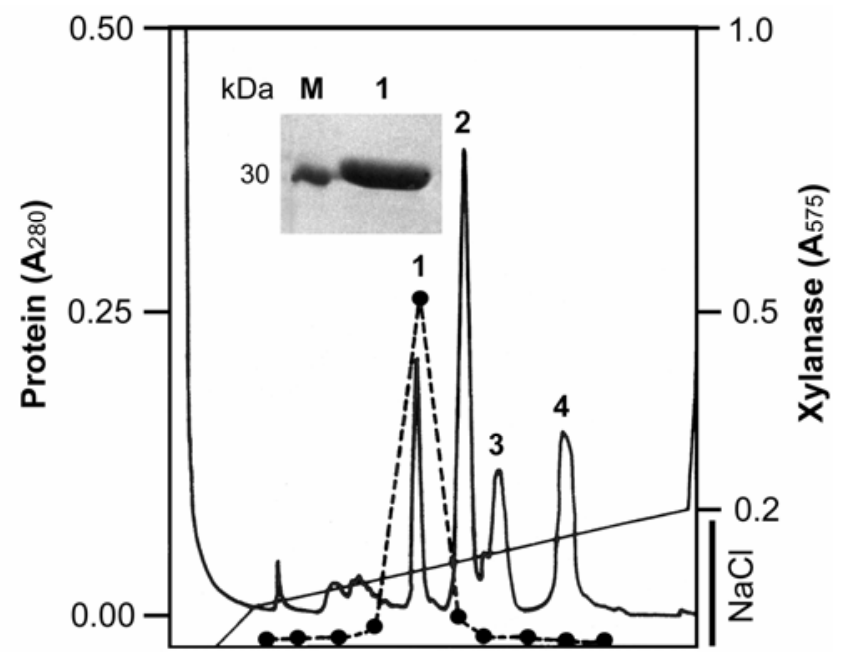

Fig. 4. Elution profile of Xanthomonas oryzae pv. oryzae secreted proteins from a MonoS column. The proteins were precipitated from culture filtrates with $55 \%$ (wt/vol) ammonium sulfate, desalted by dialyzing against $5 \mathrm{mM}$ Tris-Cl buffer, $\mathrm{pH}$ 6.5, and loaded onto the column. After a wash in buffer, the proteins were eluted with a 0 to $0.2 \mathrm{M} \mathrm{NaCl}$ gradient in the same buffer (solid line). Fractions showing absorbance at $280 \mathrm{~nm}$ $\left(\mathrm{A}_{280}\right)$ were collected and assayed for xylanase (dashed line). Inset shows sodium dodecyl sulfate polyacrylamide gel electrophoresis of purified xylanase appearing as a single band of approximately $32 \mathrm{kDa}$ (lane 2), along with molecular mass standard (lane 1). The gel was stained with Coomassie Blue R250.

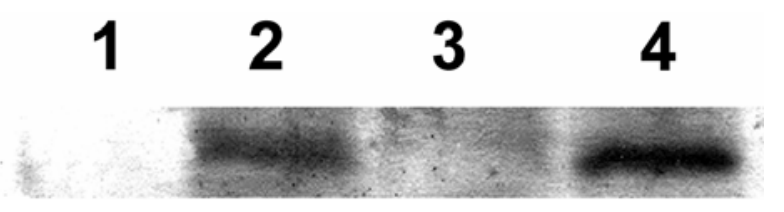

Fig. 5. Western analysis for in planta expression of XynB protein in infected rice leaf exudates using anti-XynB antibodies. Xylem sap from lane 1: uninoculated leaves or leaves inoculated with lane 2: wild-type strain; lane 3: BXO201 (xynB1::Ty2); and lane 4: BXO203 (xynA1::Ty2). 
when assayed using p-nitrophenyl oleate as a substrate, thereby confirming it to be a lipase/esterase (LipA).

xyn $B$ and lipA together affect virulence

of $X$. oryzae pv. oryzae.

Degenerate primers (5'-CGCGACGCCAAGggnaaygaycc-3' forward and 5'-GCGGAGGCCACCAGCtkraaytcytt-3' reverse) designed using the CODEHOP program (Rose et al. 1998), based on the lipA homologues of $X$. axonopodis pv. citri and $X$. campestris pv. campestris, amplified a 308-bp fragment from the genomic DNA of BXO43. The sequence of this fragment (accession number AY627913) exhibited 91 and $80 \%$ sequence identity to the homologous genes of $X$. axonopodis $\mathrm{pv}$. citri and $X$. campestris pv. campestris, respectively. The fragment was cloned into the pMOS-Blue vector to obtain pGJ1. A lipA mutant (lipA1::bla; BXO2001) was generated by electroporating pGJ1 in the wild-type background. The lipA insertion site was confirmed by PCR analysis of this region using a vector-specific primer and another primer flanking the inserted region. The resulting mutant strain did not show lipase activity in enzyme assays, and the analysis of its secreted proteins revealed the absence of the peak associated with LipA in the fast protein liquid chromatography (FPLC) elution profiles and the 39-kDa band in SDS-PAGE gels (data not shown).

The purified plasmid pGJ1 was introduced into the $x y n B$ mutant strain BXO201 to generate lipA-xynB (BXO2004) double mutant, which was deficient for secreted xylanase and lipase activities (data not shown). The plasmids pRR7, which contains the $x y n B$ gene, and pRR9, which has a transposon insertion in $x y n B$, were introduced into $\mathrm{BXO} 2004$ to obtain BXO2005 and BXO2006, respectively. The BXO2001 (lipA mutant), BXO201 (xynB mutant), BXO2004 (lipA xynB double mutant), BXO2005, and BXO2006 strains were assayed along with $\mathrm{BXO} 43$ for virulence on rice. BXO2004 was severely affected for virulence, causing lesions that were only approximately $15 \%$ of those of BXO43. The BXO2001 and 201 strains were only partially affected for virulence, causing lesions that were 65 and $70 \%$ in length, respectively, compared with BXO43 (Fig. 6). Complementation with the pRR7 clone containing $x y n B$ could restore the lesion lengths to the wild-type levels in BXO2005. The virulence was severely affected in BXO2006 (approximately 14\% lesion length), which contains a clone with a transposon insertion in the $x y n B$ gene (Fig. 6). All values were statistically significant at $P<0.05$, except for the pairwise combinations of $\mathrm{BXO} 201$ versus $\mathrm{BXO} 2001$ and that of BXO43 versus BXO2005.

\section{DISCUSSION}

Here, we report the cloning, sequencing, and mutational analysis of the gene for $\mathrm{XynB}$, the secreted xylanase of $X$. oryzae pv. oryzae. The predicted 325-aa sequence of $\mathrm{XynB}$ is homologous to several members of family 10 xylanases, showing the presence of six conserved regions that are characteristic of this family (Gilkes et al. 1991; Tsujibo et al. 1997), including the two glutamic acid residues reported as essential for the activity of xylanase A in Streptomyces lividans (Moreau et al. 1994). XynB has a xylanase catalytic domain; however, unlike several other family 10 xylanases, it is smaller in size and lacks a cellulose-binding domain. The xylanase from $R$. marinus, to which XynB shows approximately $60 \%$ homology to the catalytic domain at the amino acid level, consists of 993 aa with a molecular mass of approximately 110-kDa and five different domains and belongs to family 10 of xylanases (Karlsson et al. 1997). The substrate specificity of XynB toward xylan from various sources and the nature of the xylan breakdown products are yet to be determined.
Overall, the organization of the genomic region encoding $x y n B$ is conserved between $X$. oryzae pv. oryzae, $X$. axonopodis pv. citri, and $X$. campestris pv. campestris with the only major difference that $x y n B$ is absent from $X$. campestris pv. campestris. The $x y n A$ as well as genes for uronate isomerase and hexuronate transporter are present at this locus in all three xanthomonads. The absence of a signal peptide suggests that $x y n A$ may be an intracellular xylanase. A putative intracellular xylanase, which is encoded in a gene cluster along with the gene for a secreted xylanase, has been postulated to be involved in xylan breakdown by B. stearothermophilus (Shulami et al. 1999). A gene for uronate isomerase also is located in this gene cluster in B. stearothermophilus along with several other genes involved in glucuronic acid utilization. The xylan backbone frequently is substituted with D-glucuronic acid residues, and the uronate isomerase of B. stearothermophilus is involved in metabolism of the glucuronic acid that is released from substituted xylooligosaccharides. The hexuronate transporter genes of E. chrysanthemi and B. subtilis have been shown to be involved in uptake of galacturonates and glucuronates, respectively (Haseloff et al. 1998; Mekjian et al. 1999).

Several xanthomonads were assayed for secreted xylanase activity on Remazol Brilliant Blue (RBB)-xylan plates. $X$. campestris $p v$. translucens and $X$. campestris pv. mangiferaeindicae assayed positive, whereas $X$. campestris pv. vesicatoria, $X$. axonopodis pv. citri, $X$ campestris pv. holcicola, $X$ campestris pv. pelargonii, $X$ campestris pv. campestris, and $X$. oryzae pv. oryzicola assayed negative for xylanase activity (data not shown). X. campestris pv. translucens is a pathogen of grasses like wheat, rye, barley, and similar plants and $X$. campestris pv. mangiferaeindicae is a pathogen of mango. Constitutive $\mathrm{xy}$ lanase production may be an advantage for the former because the cell walls of grasses have a high proportion of xylan. The nature of the advantage that might accrue to $X$. campestris pv. mangiferaeindicae due to constitutive production of xylanase is not known. Certain dicots such as muskmelon have been shown to possess considerable amounts of xylose-containing polymers in their cell walls (Doux-Gayat et al. 1978). The genome sequences of $X$. axonopodis pv. citri and $X$. campestris pv. cam-

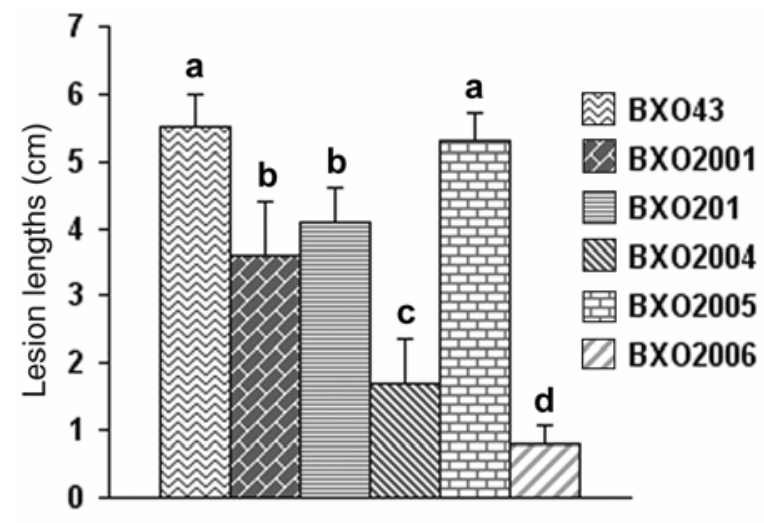

\section{$X$. oryzae pv. oryzae strains}

Fig. 6. Virulence deficiency of an xynB-lipA double mutant of Xanthomonas oryzae pv. oryzae. BXO43 (wild-type), BXO2001 (lipA1::bla), BXO201 (xynB1::Ty2), BXO2004 (xynB1::Ty2 lipA1::bla), BXO2005 (BXO2004/pRR7-xyn $B^{+}$), and BXO2006 (BXO2004/pRR9$x y n B 1:: T y 2)$ strains of $X$. oryzae pv. oryzae were inoculated on rice leaves at a concentration of $1 \times 10^{8}$ cells $/ \mathrm{ml}$ and lesion lengths were measured 7 days postinoculation. Error bars indicate the standard deviation of readings from 10 inoculated leaves. Similar results were obtained in three independent experiments. A Student's two-tailed $t$ test for independent means was performed in pairwise combinations for all the values. Values with same letter are not significantly different at $P<0.05$ level. 
pestris reveal the presence of four and three xylanases respectively, with $X$. axonopodis pv. citri having the same ORF that encodes XynB in $X$. oryzae pv. oryzae. However, neither $X$. axonopodis pv. citri nor $X$. campestris pv. campestris exhibit xylanase activity when tested on RBB-xylan plates. It is possible that the xylanases in these two bacteria are either specific for a particular type of xylan other than RBB-xylan or that they are induced under specific growth conditions.

Mutations that affect the export of extracellular proteins across the outer membrane have been shown to cause a severe virulence deficiency in $X$. campestris pv. campestris (Dow et al. 1987; $\mathrm{Hu}$ et al. 1992), E. chrysanthemi (Andro et al. 1984; Thurn and Chatterjee 1985), E. carotovora pv. carotovora (Murata et al. 1990), Ralstonia solanacearum (Kang et al. 1994), and X. oryzae pv. oryzae (Ray et al. 2000). In addition to xylanase, at least three other major proteins are secreted through the type II protein secretion system of X. oryzae pv. oryzae. One of these proteins is the lipase/esterase whereas the other two are cellulase and putative cellobiosidase (G. Jha, R. Rajeshwari, and R. V. Sonti, unpublished data). These enzymes are constitutively secreted into the extracellular medium in vitro, and Western analysis indicates that the $\mathrm{XynB}$ protein also is released into the xylem sap during in planta growth of $X$. oryzae pv. oryzae.

Mutations that affect either the secreted xylanase or lipase/ esterase have slight effects on virulence, which may be due to redundancy caused by the production of multiple cell-walldegrading enzymes in $X$. oryzae pv. oryzae. Therefore, mutations that affect a single gene would not have a significant effect on virulence. The rice pathogen $M$. grisea has been reported to produce at least five different xylanases (Bucheli et al. 1990; $\mathrm{Wu}$ et al. 1995), and mutations in genes that encode two of these proteins do not affect virulence (Wu et al. 1997). A xylanase-deficient mutant of E. chrysanthemi also retained full virulence on corn (Keen et al. 1996). Most studies with extracellular proteins secreted by $X$. campestris pv. campestris (Dow et al. 1989; Tang et al. 1987) and Erwinia spp. (Barras et al. 1994; Py et al. 1998) suggest that, individually, the proteins have either partial or no effect on virulence. However, an exopolygalacturonase (PehB) and endo-polygalacturonase (PehA) have been shown to contribute substantially to the virulence of $R$. solanacearum because double mutants are significantly reduced for virulence when compared with the individual mutants (Huang and Allen 1997). Purified xylanase from E. chrysanthemi acts synergistically with pectate lyase in causing cell killing and tissue maceration in corn and oat tissues (Braun and Rodrigues 1993).

The xylan backbone and side-chain modifications frequently are substituted with acetyl and phenolic esters. An endoxylanase and esterase from Schizophyllum commune have been shown to act cooperatively in birchwood xylan degradation (Biely et al. 1986). LipA may hydrolyze ester bonds in rice xylan, and this action may promote xylan degradation by $X$. oryzae pv. oryzae xylanases. The fact that a $x y n B$ clone restores full virulence to a lipA $x y n B$ double mutant suggests that an additional xylanase other than XynB might be acting cooperatively with LipA to degrade rice xylan. In such a scenario, the action of either XynB alone or LipA and the other xylanase would be required for normal virulence of $X$. oryzae $\mathrm{pv}$. oryzae. The severe virulence deficiency observed in the lipA $x y n B$ double mutant may be due to its inability to degrade $x y-$ lan because it lacks XynB as well as LipA, which is required by the other xylanase. Alternatively, LipA may act on a lipidic component of rice cell walls, and the loss of either this activity or XynB activity has only a slight effect on virulence, whereas loss of both activities (in the double mutant) must somehow compromise virulence. The restoration of virulence of the lipA $x y n B$ double mutant to a wild-type level, as opposed to the level of the $x y n B$ mutant, by pRR7 plasmid might be due to the extra copies of the $x y n B$ gene. The slight reduction in virulence of the lipA $x y n B$ double mutant containing pRR9, in comparison to the lipA $x y n B$ double mutant, might be due to a detrimental effect associated with the presence of this plasmid, which becomes evident only in the absence of a functional $x y n B$ gene on the plasmid. Our results, therefore, indicate an important role for xylanase in colonization of rice by $X$. oryzae pv. oryzae and point toward a functional redundancy amongst T2S-secreted proteins in promoting $X$. oryzae pv. oryzae virulence. We are pursuing these observations by constructing multiple mutations affecting the genes coding for the four T2S-secreted proteins in various combinations and assessing their effects on virulence of $X$. oryzae pv. oryzae.

\section{MATERIALS AND METHODS}

\section{Bacterial strains and media.}

Bacterial strains and plasmids used in this study are listed in Table 1 . X. oryzae pv. oryzae strains were grown at $28^{\circ} \mathrm{C}$ in PS medium (Tsuchiya et al. 1982) and Escherichia coli strains were grown at $37^{\circ} \mathrm{C}$ in Luria-Bertani medium (Miller 1992). Antibiotics and their concentrations used in this study are as follows: kanamycin $(\mathrm{Km})$ at $50 \mathrm{mg} / \mathrm{liter}$ for $E$. coli and 25 $\mathrm{mg} / \mathrm{liter}$ for $X$. oryzae pv. oryzae, Trimethoprim (Tm) at 60 $\mathrm{mg} / \mathrm{liter}$, and rifampicin (Rf) at $50 \mathrm{mg} / \mathrm{liter}$.

\section{PCR amplification.}

Genomic DNA (50 ng) of X. oryzae pv. oryzae was used for PCR as described by Rajeshwari and Sonti (2000) using two degenerate primers (forward primer: 25 mer, CACGGATC $\mathrm{CGA}(\mathrm{C} / \mathrm{T}) \mathrm{GCIACICA}(\mathrm{A} / \mathrm{G} / \mathrm{T} / \mathrm{C}) \mathrm{T}(\mathrm{A} / \mathrm{G} / \mathrm{T} / \mathrm{C}) \mathrm{TA}$; and reverse primer: 26 mer, CCAGAATTCTA(C/T) GCIACITGGTGGAT). Our original intent was to amplify the gene for a sigma factor of $X$. oryzae pv. oryzae. An error in designing the reverse primer resulted in the fortuitous amplification of the gene for secreted xylanase from the genomic DNA of $X$. oryzae pv. oryzae. The primer sequences were present within the ORF encoding XynB. The PCR product of $800 \mathrm{bp}$ was gel purified using a Qiaquick nucleotide purification kit (Qiagen Inc., Chatsworth, CA) and ligated into pMOS T-cloning vector (Amersham-Pharmacia, Uppsala, Sweden) to generate $\mathrm{pXyn} 8$.

\section{Molecular biology techniques.}

Genomic DNA was isolated as described by Leach and associates (1990) and the plasmid DNA by the alkaline lysis method (Sambrook et al. 1989). Southern hybridizations were performed as described by Rajeshwari and Sonti (2000). Restriction digestions were done with required enzymes from NEB (New England Biolabs, Beverly, MA, U.S.A.) as per the supplier's instructions. Sequencing was performed using transposon-specific primers supplied in the Primer Island Transposon kit (PE Applied Biosystems, Foster City, CA, U.S.A.) and M-13 forward and reverse primers. The sequencing reactions, electrophoresis, and sequence data analyses were performed using an ABI Prism 3700 automated DNA sequencer (PerkinElmer, Foster City, CA, U.S.A.). Homology and conserved domain searches were performed in the NCBI database by using the BLAST algorithm (Altschul et al. 1997). The signal peptide prediction program, Signal P server (Nielsen et al. 1997), and an ORF Finder program were used for the prediction of signal peptide and ORFs, respectively.

\section{Bacterial conjugation, transposon mutagenesis, and marker exchange.}

Matings between $E$. coli strains and $E$. coli (donor) with $X$. oryzae pv. oryzae (recipient) strains were carried out as de- 
scribed previously (Ray et al. 2000). Transposon mutagenesis of pRR7 plasmid DNA was done using the Primer Island Transposition Kit according to the supplier's instructions. Eighteen different Ty 2 transposable element insertions were obtained following in vitro mutagenesis of pRR7 with AT-2 (Ty2), a derivative of Ty 1 transposable element from yeast. The distribution of the transposon insertions at different regions of pRR7, as revealed by restriction mapping using single as well as double digestions with EcoRI and BamHI enzymes, is shown in Figure 1. Using outwardly directed, transposonspecific primers, the sequences flanking each of the 18 insertions were obtained. Vector-specific primers were used to obtain the end sequences of pRR7. The overlapping sequences were identified and the complete sequence of pRR7 clone was obtained (accession number AF331922, submitted in December 2000).

The Ty2 element encodes for Trimethoprim resistance. Those plasmids containing insertions in the 6,904-bp insert were mobilized individually into $\mathrm{BXO} 43$ and marker-exchange mutants were obtained by growing the transconjugants in PSTm medium for more than 30 generations by serial passage. Colonies that were $\mathrm{Tm}^{\mathrm{r}} \mathrm{Km}^{\mathrm{s}}$ were analyzed by Southern hybridization to confirm that marker exchange had occurred as expected.

\section{Virulence assays.}

Virulence assays were performed on 40- to 60-day-old greenhouse-grown plants of the susceptible rice cv. Taichung Native-1 (TN-1) by the leaf clip method of inoculation
(Kauffmann et al. 1973), and lesion lengths were measured at regular intervals.

\section{Enzyme assays.}

Assay for xylanase. Quantitation of xylanase activity was performed according to the procedure described by Biely and associates (1988). Assays for xylanase secretion were performed by spotting colonies of bacteria on PSA plates containing $0.2 \%$ RBB-xylan (Sigma-Aldrich, St. Louis) as described by Keen and associates (1996).

Assay for lipase/esterase. Lipase/esterase activity of bacterial colonies or purified enzyme spotted in wells was measured on PSA containing either $0.01 \% \mathrm{CaCl}_{2}$ and $1 \%$ Tween 80 or $1 \%$ Tributyrin (Holding and Collee 1971). White crystals surrounding colonies on medium containing $\mathrm{CaCl}_{2}$ and Tween 80 or a zone of clearing on medium containing tributyrin indicated lipase activity. Lipase/esterase activity also was performed using p-nitrophenyl oleate as described (Acharya and Rao 2002).

\section{Xylanase purification.}

Bacterial cultures were grown for $48 \mathrm{~h}$ at $28^{\circ} \mathrm{C}$ and the culture supernatant was obtained by centrifugation at $12,000 \times g$ for $20 \mathrm{~min}$ at $4^{\circ} \mathrm{C}$. All subsequent steps were carried out on ice. Ammonium sulfate fractionation was performed and the $55 \%$ fraction was collected by centrifugation at $10,000 \times g$ for $30 \mathrm{~min}$. The precipitate was taken up in $1 / 20$ original volume and salt was removed following extensive dialysis against 5 $\mathrm{mM}$ Tris- $\mathrm{Cl}$ ( $\mathrm{pH}$ 6.5). Cation-exchange chromatography was

Table 1. Strains and plasmids used in this study

\begin{tabular}{|c|c|c|}
\hline Strains or plasmids & Relevant characteristics $^{\text {a }}$ & $\begin{array}{l}\text { Reference or } \\
\text { source }^{\text {b }}\end{array}$ \\
\hline \multicolumn{3}{|l|}{ Escherichia coli strains } \\
\hline $\mathrm{DH} 5 \alpha$ & $\begin{array}{l}\mathrm{F}^{\prime} / \text { endA1 hsdR17 }\left(\mathrm{rk}^{-} \mathrm{m}_{\mathrm{k}}^{+}\right) \text {supE44 thi-1 recA1 gyrA relA1 f80dlacZDM15 } \\
\text { (lacZYA-argF) U169 }\end{array}$ & Invitrogen \\
\hline S17-1 & RP4-2Tc::Mu-Kn::Tn7 pro hsdR recA & Simon et al. 1983 \\
\hline \multicolumn{3}{|c|}{ 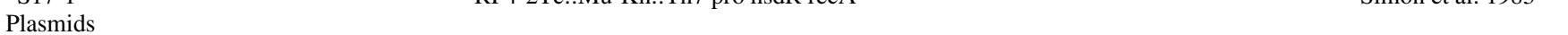 } \\
\hline pBluescript(KS) & $A p^{r}$ & Stratagene \\
\hline pMOS & $\mathrm{Ap}^{\mathrm{r}}$ & Amersham \\
\hline pUFR034 & $\mathrm{Km}^{\mathrm{r}} \mathrm{IncW} \mathrm{Nm}{ }^{\mathrm{r}} \mathrm{Tra}^{-} \mathrm{Mob}^{+} \operatorname{mob}(\mathrm{P}) \mathrm{LacZ}^{+} \mathrm{Par}^{+} \cos$ & DeFeyter et al. 1990 \\
\hline pXyn8 & pMOS +800 -bp polymerase chain reaction $(\mathrm{PCR})$ product & This study \\
\hline pRR7 & pUFR034 + 6.9-kb EcoRI fragment containing xynB gene of $X$. oryzae pv. oryzae & This study \\
\hline pRR8 & pBluescript $+6.9-\mathrm{kb}$ EcoRI fragment containing $x y n B$ gene of $X$. oryzae pv. oryzae & This study \\
\hline pRR9 & pRR7-xynB1::Ty2; pRR7 containing an insertion in $x y n B$ gene of $X$. oryzae pv. oryzae & This study \\
\hline pGJ1 & pMOS-Blue + 308-bp PCR-amplified fragment of lipA gene of BXO43 & This study \\
\hline \multicolumn{3}{|l|}{ Xanthomonas spp. } \\
\hline$X$. axonopodis pv. citri \# F1 & $\ldots$ & J. Leach \\
\hline$X$. campestris pv. translucens \# 105 & $\ldots$ & J. Leach \\
\hline$X$. campestris pv. vesicatoria \# 65-2 & $\ldots$ & J. Leach \\
\hline$X$. campestris pv. holcicola \# 86 & $\ldots$ & J. Leach \\
\hline X. campestris pv. mangiferaeindicae \#2913 & $\ldots$ & J. Leach \\
\hline$X$. campestris pv. pelargonii \# S1 & $\ldots$ & N. Sakthivel \\
\hline X. campestris pv. campestris \# 8004 & $\ldots$ & M. Dow \\
\hline$X$. oryzae pv. oryzicola \#BXOR1 & $\ldots$ & Lab Collection \\
\hline \multicolumn{3}{|l|}{$X$. oryzae pv. oryzae strains } \\
\hline BXO1 & Laboratory wild type; Indian isolate & Lab collection \\
\hline BXO43 & rif- 2 ; derivative of $\mathrm{BXO} 1$ & Lab collection \\
\hline $\mathrm{BXO} 201$ & xynB 1::Ty2 rif- $2 ; \mathrm{Tm}^{\mathrm{r}} \mathrm{Xyn}^{-}$derivative of $\mathrm{BXO} 43$ & This study \\
\hline $\mathrm{BXO} 202$ & xynB2::Ty2 rif-2; $\mathrm{Tm}^{\mathrm{r}} \mathrm{Xyn}^{-}$derivative of $\mathrm{BXO} 43$ & This study \\
\hline $\mathrm{BXO} 203$ & xynA 1::Ty2 rif-2; $\mathrm{Tm}^{\mathrm{r}} \mathrm{Xyn}^{+}$derivative of $\mathrm{BXO} 43$ & This study \\
\hline BXO204 & $\mathrm{BXO} 201 / \mathrm{pRR} 7$ & This study \\
\hline BXO2001 & lipA1:: bla rif-2; $\mathrm{Lip}^{-}, \mathrm{Ap}^{\mathrm{r}}$ derivative of $\mathrm{BXO} 43$ & This study \\
\hline $\mathrm{BXO} 2004$ & xynB1::Тy2 lipA1::bla rif-2; $\mathrm{Tm}^{\mathrm{r}} \mathrm{Ap}^{\mathrm{r}} \mathrm{Xyn}^{-} \mathrm{Lip}^{-} \mathrm{Vir}^{-}$derivative of BXO 201 & This study \\
\hline $\mathrm{BXO} 2005$ & BXO2004/pRR7 & This study \\
\hline $\mathrm{BXO} 2006$ & BXO2004/pRR9 & This study \\
\hline
\end{tabular}

${ }^{\mathrm{a}} \mathrm{Ap}^{\mathrm{r}}, \mathrm{Km}^{\mathrm{r}}$, and $\mathrm{Tm}^{\mathrm{r}}$ indicate resistance to ampicillin, kanamycin, and trimethoprim, respectively; rif indicates a mutation that confers rifampicin resistance; $\mathrm{Vir}^{+}$and $\mathrm{Xyn}^{+}$indicate proficiency in virulence and xylanase activity, respectively; and $\mathrm{Xyn}^{-}$and Lip indicate deficiency in xylanase and lipase/esterase activities, respectively.

${ }^{\mathrm{b}}$ Invitrogen = Invitrogen Life Technologies, Carlsbad, CA, U.S.A.; Stratagene = Stratagene, La Jolla CA, U.S.A.; and Amersham = Amersham Pharmacia Biotech, Uppsala, Sweden. 
performed using the MonoS (HR 5/5) columns in FPLC (Pharmacia Biotechnology, Uppsala, Sweden). The desalted sample was applied to the columns equilibrated with $5 \mathrm{mM}$ Tris-Cl (pH6.5) and proteins were eluted with a 0 to $0.2 \mathrm{M} \mathrm{NaCl}$ gradient in the same buffer. The peaks obtained were assayed for enzyme activity and xylanase active fractions were pooled and concentrated in a Speed-vac concentrator (Savant Instruments, Inc., Farmingdale, NY, U.S.A.) to one-fifth of original volume and dialyzed against $5 \mathrm{mM}$ Tris- $\mathrm{Cl}(\mathrm{pH}$ 6.5). Trypsin digestion and MS-MS analysis of the purified xylanase yielded sequence tags that matched with the XynB sequence from $X$. oryzae $\mathrm{pv}$. oryzae, thus confirming it to be the $x y n B$ gene product. The enzyme was stored at $4^{\circ} \mathrm{C}$ until further use.

The prominent xylanase peak was reproducibly obtained upon FPLC separation of $X$. oryzae pv. oryzae culture supernatants during a 3-month period in which the enzyme was purified and used to raise anti-XynB antibodies as detailed below. In more recent purifications, the xylanase peak was not prominent even though the $X$. oryzae pv. oryzae strain continued to produce the secreted xylanase as observed by halo formation on RBB-xylan plates and SDS-PAGE gels; we are not certain about the reasons for this.

\section{Analysis of protein by SDS-PAGE and MS/MS.}

Proteins were analyzed by SDS-PAGE following the procedure of Laemmli (1970) and stained with either Coomassie Brilliant Blue or silver nitrate as described by Sambrook and associates (1989). Low molecular weight markers obtained from Pharmacia Biotechnology were used as standards.

For MS-MS analysis, approximately $500 \mathrm{ng}$ of each purified protein was electrophoresed on 10\% SDS-PAGE and stained with Coomassie Brilliant Blue R250 (Sambrook et al. 1989). The gel slice containing each purified protein was cut into approximately $1-\mathrm{mm}^{3}$ pieces, washed three times $(15 \mathrm{~min}$ each) with $400 \mu \mathrm{l}$ of $50 \%$ acetonitrile in $25 \mathrm{mM}$ ammonium bicarbonate $\left(\mathrm{NH}_{4} \mathrm{HCO}_{3}\right)$, and soaked in $100 \%$ acetonitrile for 5 min. The bands were dried to completion in a speed-vac concentrator. Trypsin $(20 \mu \mathrm{l}$ of sequencing grade modified, $20 \mu \mathrm{g}$ $\mathrm{ml}^{-1}$ in $25 \mathrm{mM}$ ammonium bicarbonate; Promega Corp., Madison, WI, U.S.A.) was used for digestion at $38^{\circ} \mathrm{C}$ for 16 to $20 \mathrm{~h}$. Extraction of digested fragment was done by soaking the gel pieces in $100 \mu \mathrm{l}$ of a solution containing $50 \%$ acetonitrile and $5 \%$ trifluoroacetic acid (TFA) by vigorous vortexing for $1 \mathrm{~min}$ and dried in speed-vac to complete dryness. The dried samples were further processed in the CCMB Proteomics facility to obtain sequence tags using electrospray ionization-based MS/MS with a PE-SCIEX-API-QSTAR PULSAR instrument.

\section{Antibody production and Western blots.}

Polyclonal antibodies against the purified $\mathrm{XynB}$ protein were raised in a rabbit using standard protocols (Sambrook et al. 1989). The antiserum could detect XynB protein in culture supernatants of $\mathrm{XynB}^{+} X$. oryzae pv. oryzae samples at a dilution of 1:2,000. Leaves from rice plants infected with various strains of $X$. oryzae pv. oryzae (10 leaves for each strain) were cut 10 days after inoculation at the region where the lesion ended, and the cut surface was placed in $1 \mathrm{ml}$ of water in Eppendorf tubes for $1 \mathrm{~h}$ to allow the xylem sap and bacteria to flow into the water. The bacterial cells were pelleted in a microfuge. The supernatant was concentrated to $100 \mu \mathrm{l}$ in a speed-vac and checked for protein concentration by method of Bradford (1976). The xylem exudates (supernatant) were separated by SDS-PAGE and blotted onto a nitrocellulose membrane by the semi-dry method. Western blot analysis was performed using anti-XynB antibodies with goat anti-rabbit immunoglobulin $\mathrm{G}$ conjugated to alkaline phosphatase as a secondary antibody and nitro blue tetrazolium and 5-bromo-4- chloro-3-indolyl phosphate substrate for detection, as described by Sambrook and associates (1989).

\section{ACKNOWLEDGMENTS}

We thank M. Sultana for primer synthesis, N. Nagesh for DNA sequencing, C. Sundaram for MS-MS analysis, and C. Subbalakshmi for help in running the FPLC. We are grateful to J. E. Leach, M. Ryba-White, M. Dow, and N. Sakthivel for providing bacterial strains and N. M. Rao for providing p-nitrophenyloleate. We acknowledge the help of $\mathrm{G}$. Giridharan in figure composition. G. Jha is supported by a Fellowship from the Council of Scientific and Industrial Research (CSIR), Government of India. This work was supported, in part, by a National Bioscience Award for Career Development to R. V. Sonti from the Department of Biotechnology, Government of India.

\section{LITERATURE CITED}

Acharya, P., and Rao, N. M. 2002. Anomalous ester hydrolysis in mixed micelles of p-nitrophenyloleate-triton X-100 in the presence of guanidium chloride: Implications in lipase assays. Langmuir 18:3018-3026.

Altschul, S. F., Madden, T. L., Schaffer, A. A., Zhang, Z., Miller, W., and Lipman, D. J.1997. Gapped BLAST and PSI-BLAST: A new generation of protein database search programs. Nucleic Acids Res. 25:3389-3402.

Andro, T., Chambost, J. -P., Kotoujansky, A., Cattaneo, J., Bertheau, Y., Barras, F., Van Gijsegem, F., and Coleno, A. 1984. Mutations of Erwinia chrysanthemi defective in secretion of pectinase and cellulase. J. Bacteriol. 160:1199-1203.

Bachmann, S. L., and McCarthy, A. J. 1991. Purification and cooperative activity of enzymes constituting the xylan-degrading system of Thermomonospora fusca. Appl. Environ. Microbiol. 57:2121-2130.

Barras, F., van Gijsegem, F., and Chatterjee, A. K. 1994. Extracellular enzymes and pathogenesis of soft-rot Erwinia. Annu. Rev. Phytopathol. 32:201-234.

Biely, P., MacKenzie, C. R., Puls, J., and Schneider, H. 1986. Cooperativity of esterases and xylanases in the enzymatic degradation of acetyl xylan. Biotechnology 4:731-733.

Biely, P., Mislovicova, D., and Toman, R. 1988. Remazol brilliant blue xylan: A soluble chromogenic substrate for xylanases. Pages 633-634 in Methods in Enzymology. Vol. 160. W. A. Wood and S. T. Kellog, eds. Academic Press, San Diego, CA.

Biely, P., Vrsanska, M., Tenkanen, M., and Kleupfel, D. 1997. Endo-beta1,4,-xylanase families: Differences in catalytic properties. J. Biotechnol. 57:151-166.

Bradford, M. 1976. A rapid and sensitive method for the quantitation of microgram quantities of protein utilizing the principle of protein-dye binding. Anal. Biochem. 72:248-254.

Braun, E. J., and Rodrigues, C. A. 1993. Purification and properties of an endoxylanase from a corn stalk rot strain of Erwinia chrysanthemi. Phytopathology 83:332-338.

Bucheli, P., Doares, S. H., Albersheim, P., and Darvill, A. G. 1990. Hostpathogen interactions XXXVI. Partial purification and characterization of heat-labile molecules secreted by the rice blast pathogen that solubilize plant cell wall fragments that kill plant cells. Physiol. Mol. Plant Pathol. 36:159-173.

Carpita, N. C., and Gibeaut, D. M. 1993. Structural models of primary cell walls in flowering plants. Consistency of molecular structure with the physical properties of the walls during growth. Plant J. 3:1-30.

da Silva, A. C., Ferro, J. A., Reinach, F. C., Farah, C. S., Furlan, L. R., Quaggio, R. B., Monteiro-Vitorello, C. B., Van Sluys, M. A., Almeida, N. F., Alves, L. M., do Amaral, A. M., Bertolini, M. C., Camargo, L. E., Camarotte, G., Cannavan, F., Cardozo, J., Chambergo, F., Ciapina, L. P., Cicarelli, R. M., Coutinho, L. L., Cursino-Santos, J. R., El-Dorry, H., Faria, J. B., Ferreira, A. J., Ferreira, R. C., Ferro, M. I., Formighieri, E. F., Franco, M. C., Greggio, C. C., Gruber, A., Katsuyama, A. M., Kishi, L. T., Leite, R. P., Lemos, E. G., Lemos, M. V., Locali, E. C., Machado, M. A., Madeira, A. M., Martinez-Rossi, N. M., Martins, E. C., Meidanis, J., Menck, C. F., Miyaki, C. Y., Moon, D. H., Moreira, L. M., Novo, M. T., Okura, V. K., Oliveira, M. C., Oliveira, V. R., Pereira, H. A., Rossi, A., Sena, J. A., Silva, C., de Souza, R. F., Spinola, L. A., Takita, M. A., Tamura, R. E., Teixeira, E. C., Tezza, R. I., Trindade dos Santos, M., Truffi, D., Tsai, S. M., White, F. F., Setubal, J. C., and Kitajima, J. P. 2002. Comparison of the genomes of two Xanthomonas pathogens with differing host specificities. Nature 417:459-463.

DeFeyter, R., Kado, C. I., and Gabriel, D. W. 1990. Small stable shuttle vectors for use in Xanthomonas. Gene 88:65-72.

Doux-Gayat, A., Auriol, P., Joseleau, J. P., and Touze, A. 1978. Degradation of muskmelon cell wall by the xylanases of Colletotrichum lage- 
narium. Physiol. Plant. 42:301-306.

Dow, J. M., Milligan, D. E., Jaison, L., Barber, C. E., and Daniels, M. J. 1987. A gene cluster in Xanthomonas campestris required for pathogenicity controls the excretion of polygalacturonate lyase and other enzymes. Physiol. Mol. Plant Pathol. 31:261-271.

Dow, J. M., Milligan, D. E., Jaison, L., Barber, C. E., and Daniels, M. J. 1989. Molecular cloning of a polygalacturonate lyase gene from Xanthomonas campestris pv. campestris and role of gene product in pathogenicity. Physiol. Mol. Plant Pathol. 35:113-120.

Gilkes, N. R., Henrissat, B., Kilburn, D. G., Miller, R. C., Jr., and Warren, R. A. J. 1991. Domains in microbial $\beta$-1,-4-glycanases: Sequence conservation, function, and enzyme families. Microbiol. Rev. 55:303-315.

Haseloff, B. J., Freeman, T. L., Valmeekam, V., Melkus, M. W., Oner, F., Valachovic, M. S., and San Francisco, M. J. D. 1998. The exuT gene of Erwinia chyrsanthemi EC16: Nucleotide sequence, expression, localization, and relevance of the gene product. Mol. Plant-Microbe Interact. $11: 270-276$

Henrissat, B., and Bairoch, A. 1993. New families in the classification of glycosyl hydrolases based upon amino acid sequence similarities. Biochem. J. 293:781-788.

Holding, A. J., and Collee, J. G. 1971. Routine biochemical tests. Methods Microbiol. 6A:2-32.

Hu, N. T., Hung, M. N., Chiou, S. J., Tang, F., Chiang, D. C., Huang, H. Y., and Wu, C. Y. 1992. Cloning and characterization of a gene required for secretion of extracellular enzymes across the outer membrane by Xanthomonas campestris pv. campestris. J. Bacteriol. 174:2679-2687.

Huang, Q., and Allen, C. 1997. An exo-poly- $\alpha$-D-galacturonidase, PehB, is required for wild type virulence of Ralstonia solanacearum. J. Bacteriol. 179:7369-7378.

Kang, Y., Huang, J., Mao, G., He, L., and Schell, M. A. 1994. Dramatically reduced virulence of mutants of Pseudomonas solanacearum defective in export of extracellular proteins across the outer membrane. Mol. Plant-Microbe Interact. 7:370-377.

Karlsson, E. N., Bartonek-Roxa, E., and Holst, O. 1997. Cloning and sequence of a thermostable multidomain xylanase from the bacterium Rhodothermus marinus. Biochem. Biophys. Acta 1353:118-124.

Kauffman, H. E., Reddy, A. P. K., Hsieh, S. P. Y., and Merca, S. D. 1973. An improved technique for evaluation of resistance of rice varieties to Xanthomonas oryzae. Plant Dis. Rep. 57:537-541.

Keen, N. T., Boyd, C., and Henrissat, B. 1996. Cloning and characterization of a xylanase gene from corn strains of Erwinia chrysanthemi. Mol. Plant-Microbe Interact. 9:651-657.

Kulkarni, N., Shendye, A., and Rao, M. 1999. Molecular and biotechnological aspects of xylanases. FEMS (Fed. Eur. Microbiol. Soc.) Microbiol. Rev. 23:411-456.

Laemmli, U. K. 1970. Cleavage of structural proteins during the assembly of the head of bacteriophage T4. Nature 227:680-685.

Leach, J. E., White, F. F., Rhoads, M. L., and Leung, H. 1990. A repetitive DNA sequence differentiates Xanthomonas campestris pv. oryzae from pathovars of $X$. campestris. Mol. Plant-Microbe Interact. 3:238-246.

Marchler-Bauer, A., Anderson, J. B., DeWeese-Scott, C., Fedorova, N. D., Geer, L. Y., He, S., Hurwitz, D. I., Jackson, J. D., Jacobs, A. R., Lanczycki, C. J., Liebert, C. A., Liu, C., Madej, T., Marchler, G. H., Mazumder, R., Nikolskaya, A. N., Panchenko, A. R., Rao, B. S., Shoemaker, B. A., Simonyan, V., Song, J. S., Thiessen, P. A., Vasudevan, S., Wang, Y., Yamashita, R. A., Yin, J. J., Bryant, S. H. 2003. CDD: A curated Entrez database of conserved domain alignments. Nucleic Acids Res. 31:383-387.

Mekjian, K. R., Bryan, E. M., Beall, B. W., and Moran, C. P. 1999. Regulation of hexuronate utilization in Bacillus subtilis. J. Bacteriol. 181:426-433

Miller, J. H. 1992. A Short Course in Bacterial Genetics: A Laboratory Manual for Escherichia coli and Related Bacteria. Cold Spring Harbor Laboratory Press, Cold Spring Harbor, NY, U.S.A.

Moreau, A., Roberge, M., Manin, C., Shareck, F., Kluepfel, D., and Morosoli, R. 1994. Identification of two acidic residues involved in the catalysis of xylanase A from Streptomyces lividans. Biochem. J. 302:291-295

Murata, H., Fons, M., Chatterjee, A., Collmer, A., and Chatterjee, A. K. 1990. Characterization of transposon insertion $\mathrm{Out}^{-}$mutants of Erwinia carotovora subsp. carotovora defective in enzyme export and of a DNA segment that complements out mutations in E. carotovora subsp. carotovora, E. carotovora subsp. atroseptica, and Erwinia chrysanthemi. J. Bacteriol. 172:2970-2978.

Nielsen, H., Engelbrecht, J., Brunak, S., and von Heijne, G. 1997. Identification of prokaryotic and eukaryotic signal peptides and prediction of their cleavage sites. Protein Eng. 10:1-6.

Py, B., Barras, F., Harris, S., Robson, N., and Salmond, G. P. C. 1998. Extracellular enzymes and their role in Erwinia virulence. Methods Microbiol. 27:157-168.

Rajeshwari, R., and Sonti, R. V. 2000. Stationary-phase variation due to transposition of novel insertion elements in Xanthomonas oryzae pv. oryzae. J. Bacteriol. 182:4797-4802.

Ray, S. K., Rajeshwari, R., and Sonti, R. V. 2000. Mutants of Xanthomonas oryzae pv. oryzae deficient in general secretory pathway are virulence deficient and unable to secrete xylanase. Mol. Plant-Microbe Interact. 13:394-401.

Rose, T. M., Schultz, E. R., Henikoff, J. G., Pietrokovski, S., McCallum, C. M., and Henikoff, S. 1998. Consensus-degenerate hybrid oligonucleotide primers for amplification of distantly related sequences. Nucleic Acids Res. 26:1628-1635.

Saha, B. C., and Bothast, R. J. 1999. Enzymology of xylan degradation. Pages 167-194 in: ACS Symposium Series 723, Biopolymers, Utilizing Nature's Advanced Materials. S. H. Imam, R. V. Greene, and B. R. Zaidi, eds. American Chemical Society, Washington, DC.

Sambrook, J., Fritsch, E. F., and Maniatis, T. A. 1989. Molecular Cloning: A Laboratory Manual. Cold Spring Harbor Laboratory, Cold Spring Harbor, NY, U.S.A.

Shulami, S., Gat, O., Sonenshein, A., and Shoham, Y. 1999. The glucuronic acid utilization gene cluster from Bacillus stearothermophilus T-6. J. Bacteriol. 181:3695-3704.

Simon, R., Preifer, U., and Pühler, A. 1983. A broad host range mobilization system for in vivo genetic engineering: Transposon mutagenesis in gram negative bacteria. Biotechnology 1:784-791.

Takeuchi, Y., Tohbaru, M., and Sato, A. 1994. Polysaccharides in primary cell walls of rice cells in suspension culture. Phytochemistry 35:361-363.

Tang, J. L., Gough, C. L., Barber, C. E., Dow, J. M., and Daniels, M. J. 1987. Molecular cloning of protease gene(s) from Xanthomonas campestris pv. campestris: Expression in Escherichia coli and role in pathogenicity. Mol. Gen. Genet. 210:443-448

Thurn, K., and Chatterjee, A. K. 1985. Single-site chromosomal Tn5 insertions affect the export of pectolytic and cellulolytic enzymes in Erwinia chrysanthemi. Appl. Environ. Microbiol. 50:894-898.

Tsuchiya, K., Mew, T. W., and Wakimoto, S. 1982. Bacteriological and pathological characteristics of wild-type and induced mutants of Xanthomonas campestris pv. oryzae. Phytopathology 72:43-46.

Tsujibo, H., Ohtsuki, T., Iio, T., Yamazaki, I., Miyamoto, K., Sugiyama, M., and Inamori, Y. 1997. Cloning and sequence analysis of genes encoding xylanases and acetyl xylan esterase from Streptomyces thermoviolaceus OPC-520. Appl. Environ. Microbiol. 63:661-664.

Wu, S. C., Kauffmann, S., Darvill. A. G., and Albersheim, P. 1995. Purification, cloning and characterization of two xylanases from Mag naporthe grisea, the rice blast fungus. Mol. Plant-Microbe Interact. 8:506-514.

Wu, S. C., Ham, K. S., Darvill, A. G., and Albersheim, P. 1997. Deletion of two endo $\beta$-1,4-xylanase genes reveals additional isozymes secreted by the rice blast fungus. Mol. Plant-Microbe Interact. 10:700-708

\section{AUTHOR-RECOMMENDED INTERNET RESOURCE}

National Center for Biotechnology Information (NCBI) website: www.ncbi.nlm.nih.gov 